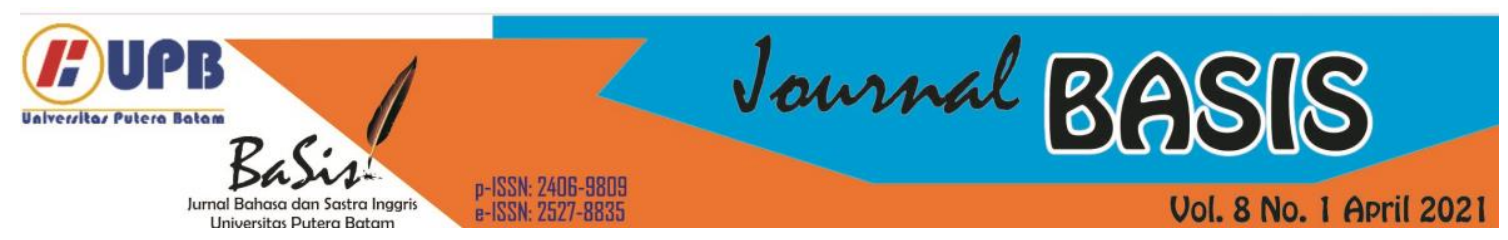

\title{
BINARY OPPOSITIONS AS THE RESULT OF DECONSTRUCTION ANALYSIS IN THE GOLDFINCH NOVEL BY DONNA TARTT
}

\author{
Cheristine Aprilia ${ }^{1}$ \\ English Department, Putera Batam University, Batam, Kepri, Indonesia \\ pb171210004@upbatam.ac.id \\ Tomi Arianto ${ }^{2}$ \\ English Department, Putera Batam University, Batam, Kepri, Indonesia \\ Tomi.arianto@puterabatam.ac.id
}

\begin{abstract}
This research is aimed to analysed the binary opposition in the "The Goldfinch" novel by Donna Tartt. The problem that analysed in this research focused on binary opposition of major character in the novel. The approach to analysing binary opposition used Derrida's concept, namely the theory of deconstruction by Jacques Derrida which is categorised as a poststructuralist approach. Deconstruction theory is understood as a theory that dismantles existing general views. The concept of binary opposition is directed to analyze the difference between two things which are considered to produce a new perspective and can be accepted by many people. The method used in this research is qualitative descriptive method, namely the author described and analysed existing data. The data is from the quotation of the novel. The result of the research is there are five binary oppositions, they are good - bad, valuable - worthless, honest - dishonest, caring - ignorant, and crowded - silent. The binary oppositions are found in the characters of the story. The characters in the story represent some of the characters of other people in the real world. People's perceptions about certain human characteristics can be explored deeper and have opposite sides.
\end{abstract}

Keywords: Binary Opposition, Deconstruction, Post-Structuralism

\section{INTRODUCTION}

Each literary work has its own language style and approach. When talking about language, there are literary works that follow. According to Wellek \& Warren (2013), literature is a creative activity that produces work of art. Literary work is a work created by an author using thoughts and feelings. Therefore, a literary work can contain inspiration and feelings of the author.

Literary works consist of various kinds. One of them is fiction. Fiction contains several aspects of a person's life. A novel is a part of fiction. A novel is not only told about a person's life story or a real incident, but a novel can also be made based on the author's imagination. A novel consists of element of fiction (theme, characterisation, plot, setting, and point of view). Reader can understand of a story based on the element of fiction.

Novel is a reading text. A reading text can be criticized using various theoretical approaches and a reader's point of view. The theoretical approach used is tailored to the needs of the researcher. If use the reader's perspective, there are many factors that influence it, namely social, psychological, experience, belief, and moral factors. Every aspect of social 
can be expressed in literature. Every aspect of life can be translated into a literary work.

A literary work can be criticized by using a text-reading strategy. This reading strategy is divided into two approaches, structuralist and poststructuralist. According to Barry (2014), structuralism have the view that a text has a static and predictable meaning, while post-structuralism have the view that a text has a meaning that is interrelated and unpredictable. The structuralist and post-structuralist views in assessing a literary work are very different, as are the strategies in reading the text. The structuralist treading strategy focuses on the internal of the text itself, but the post-structuralist comes out of the text itself but is related to the text itself.

Deconstruction theory by Derrida (1976) is the one of post-structuralist approach. This theory explains how a reading text is understood and seen not only from the structure of the reading itself, but a reading text can also be understood and seen from another side and not outside the context of the text. Deconstruction theory explains that in the reading text there are two opposing elements, which is called binary opposition. Binary opposition aims to open the reader's mind to see other meanings and not stick to one thing only. An example of the concept of binary opposition is between honesty and dishonesty.

A novel entitled "The Goldfinch" written by Donna Tartt is one example of a literary work that criticizes by using deconstruction theory. The novel tells the life of 13 years old boy, Theodore, who experienced the bombing of an art museum in New York with his mother. As a result of that crime, his mother died and all the paintings in the museum were destroyed but there was one painting that was not destroyed, namely the painting The Goldfinch, his mother's favorite painting. Apart from that, this novel also tells about Theodore's life after the death of his mother, his teenage life, and his adult life. He got into the wrong association and became an alcohol and drug addict. The researcher tried to deconstruct his work through language. The main focus of the researcher in deconstructing the text is on the binary opposition. The researcher examined this research using Derrida's theory.

The research that examines similar things has also been done by Omam Tanvir \& Nazish Amir (2017) entitled "Deconstructive Analysis Of The Short Story "Saleema" By Daniyal Mueenuddin". This research focussed on the main character, Saleema, who is considered by the surrounding people as a weak and oppressed woman. But in reality Saleema is a woman who is tough, independent, and does everything she can to get what she wants. This happens because of the detailed reading of the text which results in binary opposition in the reading.

Other research that is quite relevant is a reference in this study analyzed by Kobis (2019) regarding a comparative study: genetic structuralism on jane eyre and the great Gatsby. Arianto (2018) also implemented a postructuralism approach with Faucault theory which examines the discourse of death in the novel my sister keeper. Kasimbara (2020) can be used as a reference in research related to deconstruction with the theme of desire with a psychoanalysis approach. Even though using a psychological approach to searching behind meaning which reverses the phenomenon can be quite inspiring. but among all these studies are different from the researchers did. 


\section{THEORETICAL REVIEW}

2.1. Post-structuralist Approach

Post-structuralism is a literary and philosophical work that rejects ideas the structuralism approach. According to Barry (2014), post-structuralism accuse structuralism not following through the implications of the views about language on their intellectual system. Structuralism approach is only based on the structure, form, and framework of a text. Structuralism approach is only based on the structure, form, and framework of a text. Meanwhile, poststructuralism is different from structuralism approach. The poststructuralism argues that to understand an object, it is necessary to study and the system of knowledge that produced the object. Post-structuralism emphasize that the text is not only analysed based on its structure but based on other knowledge outside the structure of the text such as history and culture.

The role of the post structuralism approach in literature is very influential. This is because in a literary work has many aspects that can be discussed. According to the structuralism view in literary works that language has a static structure, in contrast to the poststructuralism view which considers language not to be a form that has static rules, but can be free form. The meaning of language in the poststructuralism view is free and not bound by any structure. Although free, it does not mean that meaning is taken from outside the text. The meaning of the text remains based on the inside of the text itself. That is why the post-structuralism approach influences literary work.

\subsection{Deconstrction Theory}

Deconstruction is part of the poststructuralist approach. According to Barry (2014), deconstruction discusses a text that is analyzed outside of the structure of the reading itself. Deconstruction is a theory pioneered by Jacques Derrida. According to (Derrida, 1976) deconstruction is a literary criticism theory which shows that the meaning in the reading text experiences contradictions and opposing oppositions. Unlike the structuralist approach which always relies on the structure in the text, deconstruction theory explains that outside of the text structure there are many meanings that experience differences according to the content of the text itself.

According to deconstruction theory, in literary texts there is no absolute meaning. Literary texts always produce multi-interpretative meanings (multiple interpretations). This multiinterpretation occurs when a text is read and interpreted by different readers. This is because each reader has a different point of view and opinion. This meaning will create a new interpretation when it is related to various events or situations in human life. The new interpretations in the view of post-structuralist are part of the process of the presence of a sign (sign), from the object, and binary opposition. The reader can interpret a text out of context but still pay attention to its relation to the reading text. In other words, the text is considered not to have a single definite meaning. According to Derrida (1976), small and marginalized things are important to be given meaning.

Deconstruction is a method in reading text with use conceptual and differentiation. Through differentiation, there is a binary opposition which explains that each reading text has opposite but related meanings. Binary opposition leads the reader to the uncovering and reconstruction of signs or meanings which in turn invites the reader to reflect on the philosophy of 
truth and human existence as God's creatures. The binary opposition that the writer presents and wants to break at the same time is the main strength of the story which deserves to be deconstructed.

Binary opposition explains that a text has opposite sides and does not always have one absolute meaning. This concept has the goal of not seeing a thing or problem using one side only, but it can be seen from the other side which makes more sense and has more value. The application of the concept of binary opposition can be found in the public view of a hero. Many people have the view that a hero is someone who is born perfectly, has a handsome face and complete limbs. Someone can become a hero even though his body is disabled and not handsome. One example of a hero who was born imperfect is Harun in the novel "Laskar Pelangi" (Hirata, 2008). Harun is a child who was born with a disability and even he is a poor boy in his village. Thanks to his sincerity and persistence, he managed to become a hero for his friends in fighting for their rights as children who wanted to go to school. The binary opposition concepts is divided into three parts; differance, text, and dissemination.

First is the concept of difference. This concept is to explain that one thing has many different meanings. The meaning in the text cannot be interpreted with only one particular meaning. An example is the meaning of the word "good person". There are many perceptions that define good person. There are some people who think that a good person is someone who do not take care of other people's business, but there are also those who think that if a good person does not interfere in other people's affairs, it means that the person is ignorant.
Indifference is categorized into a bad attitude.

Second is the concept of text. According to Derrida (1976), the important thing in text is "there is no outside-text" or "everything is in the text". Although according to Derrida like that, it does not mean the text is considered as a prison text. Through Derrida's discussion above, giving the meaning of a text cannot be taken from outside the text itself. The meaning must be related and in line with the text (linking each other).The example is if there is a reading text that contains the life of a prostitute. From the word prostitute, we can interpret it into two things related to the text itself, namely a job and an act that is considered despicable by society. This reading text deals with a person's personal and social life. The reader cannot relate the text of reading the life of a prostitute with meanings outside the text, such as linking the text with things that contain politics and food.

The last one is the concept of dissemination. The concept of dissemination explains that in literary texts the meaning differs but is related and cannot be connected into one meaning. According to Tyson (2006), the concept of dissemination can be understood through the following steps:

(1) Find out interpretations in the text. (2) Show the interpretations are in conflict with one another. (3) Show the conflict has resulted in new interpretations. Through this concept of dissemination, readers are directed to read more critically and be able to relate one meaning and show the opposite side of the meaning of the text in order to produce new meanings but are related to the previous meaning. One of the applications of the binary opposition concept is through reading the text of 
the novel "The Goldfinch" by Donna Tartt (2013).

\subsection{Previous Study}

There are several previous studies that can be used as references to support this research but they still have differences from several sides. The first research was written by Huiqing (2019) entitled "“Deconstruction of Binary Oppositions in John Donne's A Valediction: Forbidding Mourning". Huiqing analysed deconstruction of thought contained in the poetry of the English poet John Donne. The results of this study include the deconstruction of binary opposition such as "male vs. female", "soul vs. flesh" and "sacredness vs. worldliness".

The second research was written by Lismalinda \& Maya Silviyanti (2019) entitled "Deconstructing Binary Oppositions in The Short Story Dokter Written by Putu Wijaya". The analysis discussed about the binary oppositions, reversing the hierarchy, and finding other meanings concealed in the text. The result of the analysis consists of binary oppositions in this short story; they are doctor - shaman, God-human, modern - traditional, rich - poor, peaceful - conflict. There was a change in hierarchical position from inferior to superior along with the storyline.

The third research was written by Imas Romlah, Singgih Daru Kuncara, \& Fatimah Muhajir (2019) entitled "Deconstruction Perspective Toward the Characters in Gilman's The Yellow". The analysis focused on three characters through binary oppositions in which arising the opposite views of the previously fixed views. The results of the analysis are the findings showed that there were ten characteristics of the narrator that were opposite each other between John and Jennie. The changes in view of the characters John and
Jennie from the beginning until end of the story. The similarity with this research is that both use deconstruction theory but in different written works.

The fourth research was written by Alimorad Ahmadi, Mansour Neurouzi Mostaali \& Faramarz Piri (2013) entitled "Binary Oppositions in the Structure of Masnavi Stories". This research discussed critical between structuralism and post-structuralism which each have their views. There are two functions based on the results of this study. The results of this study are that there are researchers conducting two forms of research, the first is examining analysing the meaning lexically then proceeded with analysis in binary opposition. The similarity with this research is that both use deconstruction theory but in different written works.

The fifth research was written by Huiqing (2019) entitled "Deconstruction of Binary Oppositions in John Donne's A Valediction: Forbidding Mourning". This research used deconstructive theory by Jacques Derrida. This analysis discussed deconstruction of thought contained in the poetry of the English poet John Donne. The results of this study include the deconstruction of binary opposition such as "male vs. female", "soul vs. flesh" and "sacredness vs. worldliness". The similarity with this research is that both use deconstruction theory but in different written works.

\subsection{Theoritical Framework}

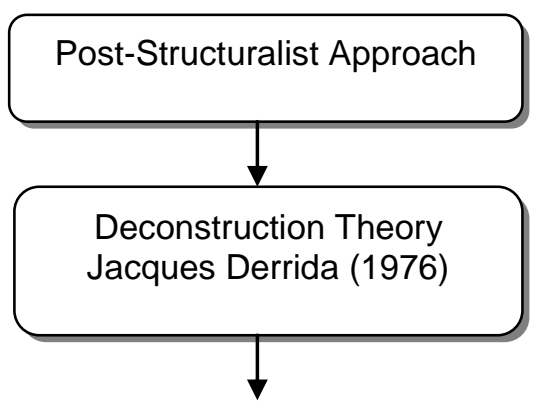


Binary Oppostion

\subsubsection{Theoretical Framework}

According to the framework above, the researcher will conduct the research by analysing The Goldfinch by Donna Tartt with deconstruction theory by Jacques Derrida. The focus of the study will be using binary opposition concept. The binary opposition will be identified in the major characters in the novel.

\section{RESEARCH METHODOLOGY}

\subsection{Reseacrh Design}

The research design of this research is applied in qualitative method. The researcher used post-structuralist approach and also theory of deconstruction by Jacques Derrida to analyse the data. The reseacher read the data and then wrote down the data which is related with the binary opposition.

\section{FINDING AND DISCUSSION}

The research question explained about the binary oppositions that is found in The Goldfinch novel. The data will be analysed by using theory of deconstruction by Jacques Derrida (1976).

\section{Good - Bad}

"I did know. Because if possible to paint fakes that look like that? Las Vegas would be the most beautiful city in the history of earth! Anyway-so funny! Here I am, so proudly teaching you to steal apples and candy from the magazine, while you have stolen world masterpiece of art." (Tartt, 2013, chapter $x$ part ix)
From the quote above, Boris did not think that Theo could steal a valuable item in The Goldfinch painting. Boris is a bad(naughty) child and has a free lifestyle, while Theo is described as a good boy and never violates school rules. There is a concept of differance, namely the perception of good children. In general, good children are described as obedient children and do not commit criminal acts. The perception like this cannot be a measure of whether someone is good or not. There are times when a good child does something bad because it is supported by several factors in his life. From the explanation, there is the concept of dissemination, which is the new perception that everyone can make mistakes, even a good person.

BORIS HAD GROWN TO like my father, and vice versa. He understood, better than I did, how my father made his living; and although he knew, without being told, to stay away from my dad when he was losing, he also understood that my father was in need of something I was unwilling to give. (Tartt, 2013, chapter v part xxvi)

From the quote above, Boris is a bad (naughty) boy who understands the situation. Even Theodore himself did not really understand his father's situation. There is a concept of differance in the perception of the nature of naughty children. Bad children are known to be troublemakers and cannot understand other people's situations. Meanwhile, good children always understand the situation of others. This situation depends on who the person is. Not all bad boys do not understand the situation, for example Boris. The concept of the text from the written deconstruction reading clearly 
shows that Boris understands and knows the right time to face Theodore's father than his son. The concept of dissemination that can be taken is that the perception that bad children only think about themselves and do not understand the situation is inappropriate because it depends on the hidden attitude of the child.

\section{"Good doesn't always follow from good deeds, nor bad deeds result from bad, does it? Even the wise and good cannot see the end of all actions. Scary idea!" (Tartt, 2013, chapter xii part v)}

From the quote above, Boris argues that good deeds will never produce good things and vice versa. Even a good and wise person cannot guarantee and know what will be obtained in the end. The concept of differance can be seen from the point of view of good and bad deeds and their results. Many people think that if someone does good thing then he will get good result, conversely if people do bad then the results will also get bad results. In the concept of text based on reading the deconstruction text, it is clearly written that there are differences in perceptions about the actions performed and the results obtained. The concept of dissemination lies in not all good things will be rewarded well either. This depends on the person responding or repaying our actions. If the person repaying with kindness, good deeds will produce something good and vice versa.

\section{Valuable - Worthless}

"Caring too much for objects can destroy you. Only - if you care for a thing enough, it takes on a life of its own, doesn't it? And isn't the whole point of things - beautiful thingsthat they connect you to some larger beauty?"(Tartt, 2013, chapter xii part vii)

According to the quotation above, for ordinary people, a painting is only an object painted by a painter and has artistic value. For the artists, The Goldfinch painting has its own meaning, namely a masterpiece by Fabritius which has extraordinary beauty meaning. For Theodore, the painting has a special meaning for him but because it has changed his life. Theo felt he had a big responsibility and had many memories with the painting. In the concept of dissemination, the assessment of an object is different for each person. This is due to internal factors, one of which is the relationship between people and objects.

\section{Honest - Dishonest}

"It would be much easier to explain to Hobie how I had happened to take the painting out of the museum in the first place. That it was a mistake, sort of. That I'd been following Welty's instructions; that I'd had a concussion. That I hadn't fully considered what I was doing.That I hadn't meant to let it sit around so long. Yet in my homeless limbo, it seemed insane to step up and admit to what I knew a lot of people were going to view as very serious wrongdoing." (Tartt, 2013, chapter iv part xiv)

According to the quote above, there are two different points of view of Theodore's actions. The difference is about whether Theo is honest or not. The concept of differance lies in Theodore's attitude in the Hobie circumstance and the outside circumstance. If in Hobie's circumstance, Theo is considered honest because he carries Welty's heirloom ring and finds Hobie's address. He can also explain what happened between 
him and Welty at the museum at the time. It's different if he's in the outside circumstance.On the other hand, it would be very difficult for Theo to explain to other people who do not know Welty that in fact he did not steal the painting of his own accord, because other people only know that he stole the painting without knowing the reason why he did this. If Theo explained to them about Welty he would be considered a liar and could not show any evidence. According to Hobie, Theo is honest but according to others who do not know Welty, Hobie, and their relationship, Theo is considered a liar. The concept of dissemination that can be taken is people's views on the concept of honesty and dishonesty. If you want to know whether the person is honest or not, the researcher has to explore facts that have happened before and how they are related.

\section{Caring - Ignorant}

Clearly a mistake had been made. "Theodore participates very little in class and appears to have no desire to expend any more attention on his studies than absolutely necessary," wrote my French professor, in a scathing midterm report that - in the absence of any closely supervising adult-no one saw but me.

From the quote above, Theodore is considered not to care about his education. He rarely studies and doesn't care about his environment. Even though he was a diligent and clever student at school first. Many people think that a good, diligent child will be forever. The concept of dissemination that can be taken is that children who were good and diligent in the past can turn into lazy and indifferent children because they are influenced by themselves and their surroundings.

"TOO MUCH EDUCATION, was my problem," said Hobie. "or so my father thought", I was in the workshop with him and helping sort through endless pieces of old cherry wood. Anyway he had me doing that from fourteen, after school and on weekends-loading boxes in the rain. At first, it was only in the summers and over Christmas vacation. But then, after my second year of college, he announced he wasn't paying my tuition anymore."'(Tartt, 2013, chapter iv part $\mathrm{xvi}$ )

The quote above explains that Hobie's father is the type of parent who ignorant of their children's education. Hobie's father indirectly told his son to work instead of spending his money on college. He trained Hobie so that from a young age, he felt how hard it was to make money so that he did not need to go to college and spend his father's money. Hobie finally dropped out of college because his father didn't pay his tuition anymore. Parents who have modern thinking will send their children to college even if they spend the money. They realize that the times now have changed and are not the same as their past. Higher education is needed especially in the modern era like today.

"So she's a stay-at-home mom? We'll look into it .Can't promise anything," he said, clicking his pen and sticking it back in his pocket. "We can certainly drop you over with these folks for the next few hours, though, if they're who you want to be with." (Tartt, 2013, chapter iii part i) 
From the quote above, Theo chose to stay with Mrs. Barbour because she is the mother of his close friend, Andy. On top of that Theo thought he would be okay and believed in his friend's family. Andy's mother is just a stay at home mother. The stay at home mothers are considered a lowly job. They are considered to have no fixed income for the future of their children. Therefore, the social worker said that the family could not promise anything to Theo. When compared to mothers who have jobs, Andy's mother is nothing. When viewed from the perspective of how to care for a child, stay at home mothers pay more attention to their children than mothers who work outside because they have more time than working mothers. This is why Theo prefers Andy's mother as his caregiver even though she is just a stay at home mother.

5. Crowded - Silent

It was all very different from the crowded, complicated, andoverly formal atmosphere of the Barbours', where everything wasrehearsed anscheduled like a Broadway production. By contrast Hobie lived andwafted like some great sea mammal in his own mild atmosphere, where every clock thehouse said something different and time didn't actually correspondtothe standard measure. (Tartt, 2013, chapter vii part vii)

From the quote above, there is a differance concept, namely crowded circumstance and silent situation. Theodore already lives in these two environments. Crowded circumstance and silent circulation have their own meaning. Many people think that crowded circumstance usually can make someone grow up to be a noisy person, but if one grows up in silent circumstance then that person becomes a calm person. This is clearly written in the text. In the concept of dissemination, if it is explored in terms of giving affection, then crowded circumstance can give more affection because living with people who are more known and loved. On the other hand, if you live in silent circumstance and a few people, the affection you get is also limited

\section{CONCLUSION}

The binary oppositions were found on The Goldfinch written by Donna Tartt and it was analysed with the theory of deconstruction by Jacques Derrida. According to the finding and discussion, binary oppositions are found in the character of the story. The binary oppositions are good - bad, valuable worthless, honest - dishonest, caring ignorant, and crowded - silent. The binary oppositions are found in the characters of the story. People's perceptions about certain human characteristics can be explored deeper and have opposite sides. From the concept of binary opposition it can be concluded that in assessing a person not only from the outside but must be more deeply familiar with and understand the character.

\section{REFERENCES}

Alimorad Ahmadi, Mansour Neurouzi Mostaali, Faramarz Piri, M. R. B. (2013). Binary oppositions in the structure of Masnavi stories. Journal of Language Teaching and Research, 4(4), 724-730. https://doi.org/10.4304/jltr.4.4.724730

Amir, O. T. \& N. (2017). Deconstructive analysis of the Short story "saleema" by Daniyal Mueenuddin. Uochjll, 1(1976), 119. 
Kobis. (2019). A Comparative Study: Genetic Structuralism On Jane Eyre And The Great Gatsby. Jurnal Basis, [S.L.], v. 6, n. 1, p. 1-12, apr. 2019. ISSN 2527-8835. Available at: <http://ejournal.upbatam.ac.id/inde x.php/basis/article/view/1054>

Arianto, Tomi. (2018). Kematian Sebagai Instrumen Kekuasaan Dalam Novel My Sister's Keeper Karya Jodi Picoult. Jurnal Basis, [S.1.], v. 4, n. 1, p. 43-54, june 2018. ISSN 2527-8835. Available at:

<http://ejournal.upbatam.ac.id/inde x.php/basis/article/view/542

Barry, P. (2014). Beginning theory: an introduction to literary and cultural theory (3rd editio). Johanneshov: MTM;Manchester University Press.

Derrida, J. (1976). Of Grammatology. Baltimore: The John Hopkins University Press.

Hirata, A. (2008). Laskar pelangi. Yogyakarta: Penerbit Bentang.

Huiqing, J. (2019). Deconstruction of binary oppositions in John Donne's a valediction: forbidding mourning. International Journal on Studies in English Language and Literature (IJSELL), 7(6), 3439.

https://doi.org/http://dx.doi.org/10.
20431/2347-3134.0706004

Kasimbara, D.C. (2020) Mango Tree's Desire In The Story Of Dengar Keluhan Pohon Mangga: Study On Psychoanalysis Of Lacan. Jurnal Basis, [S.L.], V. 7, N. 2, P. 301308, Oct. 2020. ISSN 2527-8835. Available at: <http://ejournal.upbatam.ac.id/inde x.php/basis/article/view/2480>

Romlah, I., Kuncara, S. D., \& Muhajir, F. (2019). Deconstruction perspective toward the characters in Gilman's the yellow. Jurnal Ilmu Budaya, 3(2), 185-196. Retrieved from http://ejournals.unmul.ac.id/index.php/JB SSB/article/view/1787

Silviyanti, L. \& M. (2019). Deconstructing binary oppositions in the short story Dokter written by Putu Wijaya. The 28th International Conference on Literature, 797-803. https://doi.org/10.24815/.v1i1.1454 5

Tartt, D. (2013). The Goldfinch. New York: Little, Brown and Company.

Tyson, L. (2006). Critical theory today: a user-friendly guide. New York: Routledge.

Wellek, R., \& Warren, A. (2013). Teori Kesusasteraan. Jakarta: PT. Gramedia Pustakaa Utama. 